\title{
Deliberative Law-Making: A Case Study of the Process of Enacting of a 'Constitution of the Third Sector' in the Polish Sejm
}

\author{
Piotr W. Juchacz ${ }^{1}$ (D)
}

Published online: 24 October 2019

(c) The Author(s) 2019

\begin{abstract}
The main objective of the paper is to present a model of the good practices of deliberative cooperation in a parliamentary setting. This goal is achieved through applying the three functions of the deliberative system-epistemic, ethical and democratic (Mansbridge et al. 2012) — to an analysis of cooperation between different stakeholders during the work of a Polish Parliamentary Subcommittee. They are used as an evaluative tool for analysing the cooperation of MPs, members of the public and representatives of the government (promoters of the bill). The paper analyses a concrete example of the work of the Permanent Subcommittee on the government bill amending the Act on Public Benefit Activity and Voluntary Work in the Polish Parliament. This concrete example is presented as a model of good practices when it comes to deliberative cooperation between representatives of the authorities and citizens aiming at the development of shared practical judgement. The paper consists of three parts. In the first, a systemic approach to deliberative democracy is briefly introduced, and the history of the work on the bill is outlined. The main part consists of an analysis of the three speeches of three main stakeholders in the legislative process, from the perspective of their view of legislative deliberations, and in terms of the three functions of deliberative system. In the conclusions, four main issues are analysed with reference to the presented legislative deliberations: 1. Legislative committees as mixed deliberative spheres; 2 . Internal/external deliberation; 3. The distinction between stakeholders/ordinary citizens; and 4. Deliberative stance/deliberative mindset.
\end{abstract}

Keywords Systemic approach · Deliberative democracy · Functions of deliberative system $\cdot$ Parliamentary subcommittee deliberations $\cdot$ Mixed deliberative spheres

Piotr W. Juchacz

juchaczp@amu.edu.pl

1 Faculty of Philosophy, Adam Mickiewicz University, Szamarzewskiego Street 89C, 60-568 Poznan, Poland 


\section{Introduction}

\subsection{Introducing the Research Perspective: A Systemic Approach to Deliberative Democracy}

From the outset, deliberation in legislative bodies constituted one of the core themes of the theory of deliberative democracy [7: 53-54]. Although this current of investigations is represented by quite a few researchers, certain books influenced and contributed to the development of the whole deliberative paradigm, such as: Joseph M. Bessette's The Mild Voice of Reason: Deliberative Democracy and American National Government (1994) [4]; John Uhr's, Deliberative Democracy in Australia: The Changing Place of Parliament [43]; and Jürg Steiner's, André Bächtiger's et al. Deliberative Politics in Action. Analyzing Parliamentary Discourse (2004) [39]. ${ }^{1}$

However, new challenges arose in the study of parliamentary institutions with the emergence of the theory of deliberative democracy in the third, systemic phase of its development. $^{2}$

The first phase, which is characterized by an epistemic-procedural approach to deliberative democracy, was a period involving the formulation of counterfactual models of ideal deliberative procedures and formal definitions of deliberative democracy. This period can be identified with the years 1980 to 1996, which was dominated by the thought of the two most eminent representatives of the deliberative paradigm: Habermas [18, 19] and Rawls [37]. ${ }^{3}$ In addition to their writings, the most important works of this period include Cass Sunstein's articles, such as Naked preferences and the constitution (1984) [40] and Interest groups in American public law (1985) [41], Jon Elster's The market and the forum (1986) [11], Bernard Manin's On legitimacy and political deliberation (1987) [26], Joshua Cohen's Deliberation and democratic legitimacy (1989) [8] and Jane J. Mansbridge's The rise and fall of self-interest in the explanation of political life (1990) [27].

The second phase, which conventionally corresponds to the period from 1996 to 2012, is characterised by an institution-practical and empirical approach to deliberative democracy. It was a period of various attempts to introduce the basic principles of the deliberative ideal into the institutional practice of the everyday functioning of the democratic system, on the one hand by creating and introducing new participatory-deliberative models for the public involvement of citizens, and on the other by empirical research on the functioning of already existing democratic institutions and indicating the possibility of their reconstruction through a wider introduction

\footnotetext{
1 There is also a limited (in comparison with other deliberative issues) but very instructive set of articles that analyse deliberation in parliamentary settings, such as for example: [2, 3, 15, 34, 44].

2 Some researchers single out four instead of three generations in the development of deliberative democratic theory, see [12].

3 John Rawls, Political Liberalism [37]. It should be borne in mind that in this book Rawls presents ideas developed in articles published in the second half of the 1980s, such ideas as: the fact of pluralism of reasonable comprehensive doctrines, the complementarity of the reasonable and the rational, burdens of judgement, overlapping consensus, and public reason. These concepts began to play a fundamental role in deliberative discourse and had a tremendous impact on the development of this current.
} 
of deliberative elements. In this period, three fundamental changes in the research orientation of deliberative democrats took place, which John S. Dryzek described as: the institutional turn, the practical turn and the empirical turn [11: 6-9].

The third phase, which is characterised by a systemic approach to deliberative democracy, was a period of broadening the research perspective by introducing a more extensive analysis of democratic institutions in the context of their functioning within the whole deliberative system. The first use of the phrase 'deliberative system' can probably be traced to Bernard Manin's famous article On legitimacy and political deliberation (1987) [26]. ${ }^{4}$ Although the article itself belongs to the core literature of the first phase of the development of the theory of deliberative democracy, the use of the phrase was accidental and not connected with the development of a definition and a broader analytical perspective. Jane Mansbridge's article Everyday talk in the deliberative system (1999) [28], where she offered the first approximate definition of the concept of the deliberative system and rephrased the meaning of deliberation by steering it towards the everyday talk of ordinary citizens, is commonly referred to as the place where the term and concept of the deliberative system was introduced [28].

In addition, the most important articles in in the early period of shaping a new systemic approach to deliberative democracy include: Robert E. Goodin's Sequencing deliberative moments (2005) [15]; Carolyn M. Hendriks' Integrated deliberation: reconciling civil society's dual role in deliberative democracy (2006) [20]; Dennis Thompson's Deliberative democratic theory and empirical political science (2008) [42]; and John S. Dryzek's Democratization as deliberative capacity building (2009) [9]; as well as the following books: John Parkinson's Deliberating in the Real World. Problems of Legitimacy in Deliberative Democracy (2006) [32]; and John S. Dryzek's Foundations and Frontiers of Deliberative Governance (2010) [10]. Proponents of the systemic approach often state that they drew inspiration from Jürgen Habermas' Between Facts and Norms (1996) [19], in which the German philosopher outlined two-track model of deliberative politics, with the public opinion formed on the periphery and political will formation in the centre, which — despite numerous fundamental differences - is consistent with the systemic approach they developed [5: 222-241].

However, the breakthrough moment for the 'systemic turn' in the theory of deliberative democracy was the publication in 2012 of the book Deliberative Systems. Deliberative Democracy at the Large Scale by a group of authors centred around Jane Mansbridge [33]. In the opening programmatic article, entitled A systemic approach to deliberative democracy, Jane Mansbridge, James Bohman, Simone Chambers, Thomas Christiano, Archon Fung, John Parkinson, Dennis F. Thompson and Mark E. Warren outlined the research perspective and fundamental concepts of this theory. ${ }^{5}$

\footnotetext{
${ }^{4}$ Manin wrote: "Nevertheless the structure of the deliberative system usually makes the protagonists strive to enlarge their points of view and propose more and more general positions. There is a sort of competition for generality. The deliberative process never results in strictly universal proposals; universality remains the unattainable end, but the system provides an incentive to generalization" [26: 359].

5 [29] In the article, the authors declared that the systemic approach "reached a point that makes it possible and desirable to begin a third phase" of the development of the theory of deliberative democracy (p. 26). Many fundamental ideas of the new systemic approach were also developed in the same collected volume.
} 
A definition of the deliberative system, the boundaries of the deliberative system, including a new broader definition of deliberation, the types of decisions included in the deliberative system and its institutions, the functions of the deliberative system and new standards for evaluating the institutions of the deliberative system-all these concepts were analysed and sketched out, thereby starting a broader and more detailed discussion in the new systemic approach. The analytical power and usefulness of all of these concepts are to be checked in a deliberative research practice. Recently Parkinson expressed this directly in the concluding words of his article Deliberative Systems: "There is a great deal of exciting work to be done, but doing it is going to require deliberative democrats to think about their enterprise anew" [35: 432, emphasis added].

Mansbridge et al. point out that "In the systemic approach, we assess institutions according to how well they perform the functions necessary to promote the goals of the system" [29: 11]. They identify three basic functions of the deliberative system: epistemic, ethical and democratic. It is important to stress that the introduction of these three functions as the criteria of judgement for the functioning of a democratic institution as part of the deliberative system of representative democracy concerns both the types of institutions characteristic of real democracy, namely those which strive to adopt internally deliberative standards, and those which include non-deliberative practices. In both cases the analysis concerns the level of internal functioning as well as the systemic level. It is possible that a deliberative institution without any executive power of influence on public policy fulfils the functions on the internal level but fails to contribute to the endorsement of a deliberative system on the systemic level (in any case, we do not claim that all institutional deliberation has to be connected with binding decisions). It is also possible that an internally non-deliberative institution-such as for example the public hearing in the Polish Sejm-fulfils all three functions of the deliberative system on the systemic level (see [22: 686]).

According to Mansbridge et al. the goal of the epistemic function of a deliberative system "is to produce preferences, opinions, and decisions that are appropriately informed by facts and logic and are the outcome of substantive and meaningful consideration of relevant reasons" [29: 11]. Put briefly, a properly designed institution of a deliberative system will encourage the inclusion of more knowledge from numerous points of view. In the context of the legislative process analysed below, this means thorough deliberation of all presented arguments and justifications, so that no part of the public knowledge involved is ignored or rejected without judicious deliberation.

The primary goal of the ethical function "is to promote mutual respect among citizens ... [which] helps keep the deliberative system running ... [and] serves as the lubricant of effective communication" [29: 11]. Mansbridge et al. note that mutual respect - which is, on the one hand, a value in itself and, on the other hand, a basis for citizens to acknowledge each other as autonomous political decision-makers-is assumed to be a fundamental feature of various theories of democracy. Nevertheless, in their opinion, it has special significance for the supporters of deliberative 
democracy, since "mutual respect [...] is intrinsically a part of deliberation" [29: 11]. There is no deliberation without the rejection of domination and deception, and without recognising each participant as an autonomous subject who is capable, on the one hand, of formulating and justifying their own position and, on the other, of considering and accepting the justifications put forward by their fellow citizens. Although the condition of mutual respect between citizens is not a distinguishing feature of the systemic approach to deliberative democracy, its importance has been emphasised from the very beginning of its development. In Why deliberative democracy? Amy Gutmann and Dennis Thompson described mutual respect as "a virtue that lies at the core of moral deliberation in a democracy" [16: 79]. In the context of the presented analysis of deliberation in the Polish Parliament (the Sejm), the ethical function concerns promoting mutual respect between, on the one hand, members of parliament and the representatives of the government (promoters of the bill) and, on the other hand, between these representatives of the authorities and members of the public.

The essential goal of the democratic function is "the inclusion of multiple and plural voices, interests, concerns, and claims on the basis of feasible equality ..." [29: 12]. Mansbridge et al. put it very clearly: "Who gets to be on the table affects the scope and content of the deliberation" [29: 12]. In the case of the legislative process analysed below, the fulfilment of democratic function means incorporating the new viewpoints and the interests of a greater number of stakeholders. This means really involving as many stakeholders of a bill that were interested as possible in the legislative process, and enabling them to present their ideas.

Mansbridge et al. point out that if a given institution strengthens all-or even one of - these functions, this serves to promote the legitimacy of the deliberative system, in the relevant area. In this paper I undertake the task of applying the three functions of the deliberative system as an evaluative tool for analysing the cooperation of MPs, members of the public and representatives of the government (promoters of the bill) during the work of the Permanent Subcommittee on the issue of cooperation with non-governmental organizations on the government bill amending the Act on Public Benefit Activity and Voluntary Work in the Polish Sejm. In the following considerations, I would like to present this concrete example of the work of one of the Polish Sejm Subcommittees as a model of good practices when it comes to deliberative cooperation between representatives of the authorities and citizens. Due to its fundamental importance for the functioning of the third sector' in the public sphere in Poland, Jan Jakub Wygnański described this law as "the constitution of the mutual relations between the public administration and the third sector". 6

\footnotetext{
${ }^{6}$ A citation from the statement by Wygnański during the meeting of the Social Policy and Family Committee. It was Wygnański who used the term 'constitution of the third sector' in his speech, and which is used in the title of this article. See [51:5].
} 


\subsection{A Brief History of Work on the Government Bill Amending the Act on Public Benefit Activity and Voluntary Work}

The first government bill amending the Act on Public Benefit Activity and Voluntary Work and some other acts was submitted to the Sejm on 5 June 2007. In the Explanatory Memorandum to the bill, it was indicated that at the stage of ministerial work, broad public consultations were conducted, in which seventy-four civil society entities took part [55: 20-22]. It is worth noting that as early as at the first meeting of the Committee on Social Policy, which was held on 27 June 2007, Tadeusz Tomaszewski, MP, stressed the need to involve the widest possible group of stakeholders in the work on the bill, [saying]: "I think that since this project was prepared in cooperation with the Public Benefit Council, the only problem is to promote it well, so that as many NGOs and local self-government units as possible would like to become involved and pass on their experience in the work on this law [...] [46: 6].

The MPs also submitted a proposal to hold a public hearing on the bill, which was supported by the representative of the promoters of the bill [46: 8]. At the same Commission meeting, after the first reading of the bill, a group of MPs made a formal proposal to that effect and the Commission voted unanimously in favour of a public hearing on 4 September 2007. ${ }^{7}$ On the same day, the Social Policy Committee appointed an extraordinary subcommittee to consider the government's bill.

However, 3 days later, on 7 September 2007, after less than 2 years of operation, the Sejm of the fifth term of office decided to shorten it. In connection with the customary principle of discounting parliamentary work in the Polish Sejm, all pending legislative work is extinguished, ${ }^{8}$ and this is what happened with the bill presented by the government.

After the formation of a new Sejm and a new government formed by a different coalition of parties, work on the bill was resumed, by carrying out broad social consultations once again at the pre-parliamentary stage. ${ }^{9}$ Six regional conferences and one central conference were organised. In the Explanatory Memorandum to the bill, the promoters of the bill mention sixty three NGOs actively participating in the consultations. In addition, the bill was consulted with representatives of local selfgovernment units, which also actively contributed, and representatives of churches and religious associations. The Council for Public Benefit Works was a permanent partner at all stages of the bill's preparation [54: 21-22].

\footnotetext{
7 Record of the public hearing, see: [47].

8 There are several exceptions to this rule, such as with regard to the bills from the initiative of citizens (legal basis: the Act of 24 June 1999 on the exercise of legislative initiative by citizens, Article 4(3): "3. A bill with respect to which the legislative proceedings have not been completed during the term of office of the Sejm in which it was submitted, is considered by the next term of office of the Sejm without the need to resubmit the bill. In such a case, the Speaker of the Sejm orders the reprinting of the bill and its delivery to the MPs".

9 This was confirmed by Krzysztof Więckiewicz, Director of the Public Benefit Department of the Ministry of Labour and Social Policy, during the meeting of the Social Policy and Family Committee on 19 March 2009: "The bill amending the Act [...] is a document that was extensively and deeply amended and consulted with the NGO sector". See [48: 4].
} 
As a result of these activities, on 17 February 2009 the government submitted a new bill to the Sejm. ${ }^{10}$ Similar to 2007 , when justifying the necessity of its introduction, the promoters of the bill explained that "the dynamic development processes occurring in the last 5 years and more, falling within the period of Act's validity, and the conclusions drawn from its supervision clearly indicated the need to introduce new regulations concerning key issues related to public benefit activities" [54:1]. Among the MPs, we can note the awareness of the scope of work and consultations on the bill so far, as is evident from the words of Tadeusz Tomaszewski (Lewica [the Left]): "We have the amendment of the Act on the table. This is a step in the right direction. Only the scope of consultations that were conducted and the number of entities taking part in them justifies the fact that it is ready much later than the government had intended. This law was supposed to have been ready at least a year earlier, but it is precisely these consultations with the non-governmental sector, and with local self-government and other entities [...] that meant it was only possible for us to start work in parliament today" [48: 9].

At the meeting of the Committee on Social Policy and Family Policy on 19 March 2009, representatives of both the main parties present in the Sejm and the promoters of the bill expressed support for further work on the bill and for the idea of organizing another public hearing, ${ }^{11}$ which was held on 21 April 2009 [49]. Two days later, during the meeting of the Committee, the government bill was submitted to a permanent subcommittee for cooperation with non-governmental organisations and the MP T. Tomaszewski was appointed as its chair [50: 10]. The Parliamentary Subcommittee convened ten times, on 7 and 19 May, 18 and 23 June, 16 July, 27 August, and 2, 8, 10 and 23 September 2009. ${ }^{12}$ On 7 and 8 October 2009, the report on the work of the Sejm subcommittee was presented by its chairman, MP Tomaszewski, during the meetings of the Social Policy and Family Committee. The report was adopted unanimously, and Tomaszewski himself was appointed as the rapporteur to present the bill during the plenary session of the Sejm [52: 22].

Unfortunately, reconstructing the works of subcommittees is not an easy task, since the transcripts of Sejm Subcommittee meetings, which take place after the public hearings and which constitute the next stage of the legislative process, and which constitute the most crucial stage in the legislative process, are not published

\footnotetext{
10 A record of subsequent stages of the legislative process over the government bill amending the Act on public benefit activity and volunteering and some other acts (Print 1727, 17-02-2009) is available at: http://orka.sejm.gov.pl/proc6.nsf/opisy/1727.htm.

11 [48]. A quotation from the statement of the Secretary of State in the Ministry of Labour and Social Policy, Jarosław Duda: "In connection with the fact that we touch on a very important matter, I wanted to express my satisfaction that the Commission wanted to submit a request for a public hearing, because it is very important" [48: 3]; a quotation from MP Izabela Jaruga-Nowacka (Lewica [Left]): "I also want to express my joy that the bill is received late, but it was consulted with NGOs. After all, it is also their expert knowledge of the obstacles they have encountered in 5 years that is needed if we are to improve this situation" [48: 10]; a quotation from the statement by Teresa Wargocka (PiS [Law and Justice]): "I also wanted to express my satisfaction with the fact that we can proceed with the bill on public benefit" [48: 7].

12 See: http://orka.sejm.gov.pl/SQL.nsf/poskomprocall?OpenAgent\&6\&1727.
} 
at all, and in fact are not available to the public. ${ }^{13}$ In principle, only transcripts and video recordings of Sejm plenary meetings in full chamber and committee deliberations are available on the webpage of the Polish Sejm.

This state of affairs is not an exception to parliamentary practice throughout the world. Quirk et al. pointed out that "In the US Congress, during most of the twentieth century, substantive deliberation occurred mainly in the committee. When bills moved from the committee to the full chamber, the other legislators usually deferred to the committee recommendations [...]" [36: 278]. In the Polish parliament the role of committee deliberations is similarly important, especially because contentious issues are in practice finally decided on at this stage of the legislative process. But the real legislative work, substantive and meaningful deliberation, takes place in the subcommittees.

Nevertheless, it is sometimes possible to gain a partial insight into what transpired during the sessions of the Sejm subcommittee, if information pertaining to this appears during the subsequent sessions of the Sejm committee, which most often happens during committee meeting at which a Subcommittee Chair officially reports to the Sejm committee on the course and results of its deliberations. And such an opportunity was used in the analysis presented in the main section of this article. My considerations concerning the deliberative cooperation of all the interested parties is based on an analysis of the speeches of representatives of the main interested parties during the final session of the Social Policy and Family Committee of the Polish Sejm.

\section{Deliberative Law-Making ${ }^{14}$}

It is worth citing three complementary statements made by participants of these legislative deliberations, which present the vision of the Subcommittee's work from the perspectives of the legislators, the promoters of the bill and the citizens. Let us begin by citing a part of the long speech from the Chair of the Sejm Subcommittee, Deputy Tadeusz Tomaszewski (Left), in which he reports on the progress of public consultations and the work of the Subcommittee:

\subsection{Speech 1.a}

"The government, while preparing the amendment to the Act on Public Benefit Activity and Voluntary Work and some other acts, conducted an extensive consultation with the public on this issue. They began at the end of 2007 and continued throughout 2008. The project was submitted to the Sejm on February 16, 2009. As part of the consultations [...] a public hearing was held. The suggestion of the Committee Chair,

\footnotetext{
13 Their availability at all is highly limited, as they can be accessed only as voice records at the Parliamentary library.

14 This part of the article is based on the par. 3.1 of chapter 12 in my Polish book Deliberatywna filozofia publiczna [Deliberative Public Philosophy] [22].
} 
but also the readiness of the government and members of the public, contributed to the fact that the work on the bill proceeded in an atmosphere of understanding, with all the participants seeking the best solutions on the basis of a governmental project. Therefore, each meeting of the Subcommittee was preceded by seminars, meetings and discussions between representatives from the public and the government party. The points of agreement reached at the meetings were presented at the Subcommittee meetings and adopted by its members. The Permanent Subcommittee for cooperation with non-governmental organizations sat on ten occasions. Cooperation with the public involved the participation of representatives from various organizations that desired to put forward some solutions to the project. Everyone who expressed the desire to contribute was invited to the Subcommittee meeting. There were no situations in which I refused anyone's participation in the meetings. The Subcommittee has completed its work and submits the report. A decision has not been made, as it is acknowledged that this is an important problem, as to the issues [...]" [51:3-4].

Similarly, the representative of the promoters of the bill, the Secretary of State in the Ministry of Labour and Social Policy, Jarosław Duda, emphasized the effective cooperation between the government, deputies and the public in his statement:

\subsection{Speech 1.b}

"You can see here the effect of over a dozen months of work. [...] This is not only the result of government work. This is the effect of months of seeking agreement and arriving at certain decisions that were supposed to be the best possible in the circumstances. Nevertheless, in some cases we were not able to reach unanimous agreement. This issue of the one percent tax mechanism and the problem of businesses have yet to be decided. However, here too, we have developed positions to be implemented in a certain time frame. [...] Once again, I would like to thank representatives from the public, the Council for Public Benefit Activity, ${ }^{15}$ and the Chair of the Subcommittee for this fruitful cooperation and atmosphere during the work on the bill. Thank you very much" [51:5].

These statements and the report on the work of the Subcommittee mentioned above are completely consistent with the statement from the representative of 'critical citizens' [see 30]. Therefore, as the third statement, I will cite the description of the work on the bill provided by Jan Jakub Wygański, the President of the Forum for Non-governmental Initiatives (and who in the years 2003-2006 was a member of the Council for Public Benefit Activity):

\subsection{Speech 1.c}

"I would also like to add my thanks. I do not think I can remember a precedent for such a well consulted bill. There were two public hearings. The honourable Mr.

\footnotetext{
${ }^{15}$ For information concerning the Council for Public Benefit Activity, see: https://pl.wikipedia.org/wiki/ Rada_Dzia\%C5\%82alno\%C5\%9Bci_Po\%C5\%BCytku_Publicznego.
} 
Tadeusz Tomaszewski supervised the work of the Subcommittee very efficiently and agreed to let us take part in consultations very often and take advantage of this opportunity. We participated in many seminars together with the government party. There were over twenty of them. Not only did many representatives of the Council for Public Benefit Activity participate in them, but many non-governmental organizations did also. [...] It was a lively forum for the exchange of views. At this point, I would like to thank the representatives of the government [...] and employees of the Department of Public Benefit in the Ministry of Labour and Social Policy [...]. In my view, the outcome of the process is impressive and proves that the work of the Council for Public Benefit Activity really makes sense and allows us to reach a very broad consensus, despite the issues that have yet to be resolved and which were subject to some controversy. It was very encouraging that at no stage in the work of the subcommittee was there any hint of political divisions. This was previously unheard of. We all worked in concert, which is promising for further work on the bill" [51: 5-6].

The above statements constitute a model description of the cooperation between deputies, government promoters of the bill and interested citizens for the purpose of improving the bill. It is worth emphasizing some essential features of this deliberative cooperation:

1. First, the assumption that broad public consultations are constructive. Even if making such an assumption is an exception rather than the rule in the Polish Sejm, since often deputies express the view that public consultations only prolong the legislative process, and do not contribute anything new. It is of paramount importance to highlight how the ethical function of the deliberative system was fulfilled by the mutual recognition and demonstrated readiness to cooperate, which resulted in the fact that "work on the bill proceeded in an atmosphere of understanding" (Tomaszewski, 1.a) and "we all worked in concert" (Wygnański, 1.c).

2. Second, searching for the best solutions together. The adoption of the assumption that broad public consultations are constructive also results in the joint efforts of representatives of all three groups involved (legislators, promoters, public stakeholders) to seek "the best solutions on the basis of a governmental project" (1a). Joint cooperation in order to create the best law fulfils the epistemic function of the deliberative system.

3. Third, the readiness to cooperate expressed by all three parties involved in the legislative process. This aspect of cooperation is particularly evident in Tomaszewski's speech, when he emphasizes "The suggestion of the Committee Chair, but also the readiness of the government and members of the public contributed to the fact that the work on the act proceeded in an atmosphere of understanding, with all the participants seeking the best solutions on the basis of a governmental project"'(1a) and in Wygnański's words, when he expresses his appreciation for the work of the Subcommittee chairman, who "agreed to let us take part in consultations very often and take advantage of this opportunity" (1c). It should be noted that the initiative for broad cooperation came from the legislators in the form of an incentive from the Chair of the Committee for Social and Family 
Policy (and its subsequent implementation by the Chair of the Subcommittee), and was accepted by both the government and representatives of the public. The agreement of the parties was not a foregone conclusion, since it required a certain amount of self-restriction from the outset: on the one hand the government party signaled that it was open to a broad debate on all its provisions, despite having invested a great deal of time and considerable resources in preparing the bill and submitting it to interministerial consultations; on the other hand, representatives of the public agreed at the outset that the basis for the consultations would be a bill prepared by the government. This mutual willingness to cooperate, expressed by all three parties involved in the legislative process, constituted a general framework enabling the implementation of all the functions of the deliberative system. It is an expression of the mutual recognition of the participants of deliberation as being equal partners (despite the differences in positions and roles) in the deliberation on the bill (the ethical function), which entails the mutual recognition of appropriate competences-substantive (knowledge) and communicative (reasonableness), which ensures participation in the deliberation will be constructive (the epistemic function), and which in turn also allows the full inclusion of the public (the democratic function).

4. Fourth, proposing and implementing the decision to conduct a public hearing. The reluctant attitudes of some deputies to this institution may be demonstrated on the one hand by the small number of requests to conduct public hearings in the Polish Sejm, and on the other there are many sceptical statements on this issue. For example, in this regard it is worth mentioning the reaction of one deputy to the request for a public hearing: "I don't know who will want to come to this. We will be going over the same points again and again, and the result will be that we'll talk to each other, but what next? In my opinion, this is an artificial procedure" [53: 26]. The decision to organize a public hearing satisfies the normative claims of citizens and fulfils the democratic function of the deliberative system. In the Polish political system, the institution of public hearing is the most inclusive one (comparable only to a national referendum), as every interested citizen can express his or her interest in participation in the public hearing by filling in an application form, and only procedural reasons (for example, sending the application form too late) are the basis of rejecting his or her participation. Unfortunately, the institution of public hearing is very rarely employed by Polish legislators: in the years 2006-2019 only thirty-two public hearings were announced (including one that was cancelled).

5. Fifth, the organization of additional meetings and seminars. Representatives of all three parties draw special attention to the fact that in addition to deliberations at the ten meetings of the Subcommittee, twenty separate seminars and meetings were held, which preceded the official deliberations and allowed a common position to be worked out in the course of multilateral discussions. These activities fulfil the epistemic function of the deliberative system.

6. Sixth, transparency and inclusion, or the accessibility of discussions for all the interested stakeholders ("Everyone who expressed the desire to contribute was invited to the Subcommittee meeting. There were no situations in which I refused anyone's participation in the meetings.", 1a) ensured that both the 
democratic and ethical functions were fulfilled. The democratic function was fulfilled because every interested member of the public who expressed a readiness to participate in the work on the bill was invited to the meetings of the Subcommittee and thus had the opportunity to present his or her case. The ethical function was fulfilled because this open attitude on the part of the Head of the Subcommittee undoubtedly contributed to building mutual recognition and trust between the representatives of the legislative, the executive (promoters of the bill) and critical citizens.

7. Seventh, the diversity of the stakeholders, which Deputy Tomaszewski drew attention to in his speech, when he said that "Cooperation with the public involved the participation of representatives from various organizations that desired to put forward some solutions to the project" (1a). This was also confirmed by Wygnański admitting that "Not only did many representatives of the Council for Public Benefit Activity participate in them, but many non-governmental organizations did also" (1c). The diversity of stakeholders involved in the legislative process ensures that the democratic function of the deliberative system is fulfilled. In subsequent discussion on the report on the work of the Subcommittee, this topic was brought up again and Deputy Tomaszewski once again stated: "As was just said-but it is worth emphasizing once again-the work on this project was carried out in a unique way: two public hearings, twenty seminars, ten Subcommittee meetings and yesterday a meeting of the parliamentary team for cooperation with non-governmental organizations. All opinions, all views, all positions could be freely presented' [51: 6]. In my opinion, it is worth placing particular emphasis on the democratic function in this case concerning the 'constitution of the third sector', since it was thanks to this feature of the Subcommittee deliberations, namely the participation of the broad diversity of stakeholders, that the collective work of all of them enabled broad public legitimacy to be attained. The assurance that there is real diversity among the stakeholders participating in the legislative process is precisely that which fulfils the (previously mentioned) requirement of good consultations, namely the accessibility of the deliberation to all the interested stakeholders. The democratic function and the assurance of diversity should not be confused with each other. For example, a public hearing is theoretically the most accessible institution of Polish democracy in the legislative process, but this formal openness, or the potential participation of any citizen in it, is frequently limited by other factors such as lack of knowledge about the hearing, lack of funds to travel to Warsaw from distant locations, being unable to attend due to work commitments on a given day, etc. These two features of good consultation (the diversity of stakeholders and accessibility for all interested) might seem obvious, but in Polish democracy this is by no means the case. There are many statements of numerous representatives of the public who emphasize that they did not have the opportunity to participate in the work on bills before the public hearing. Again, this is consistent with the arrogant belief of some deputies that it is enough if there is any representation of citizens. In this regard it is worth recalling the characteristic reaction of the Chair of the Committee on Culture and Mass Media to the request of one of the deputies to convene a public hear- 
ing, made at the end of the Committee meeting at which the first reading of the bill amending the Act on Radio and Television Broadcasting and the Act on Subscription Fees was held: "If the representation taking place today is not sufficient, then crowds will gather. I thought that this representation was enough. I think that you should expect it to last the whole day, because it will probably turn into a media conference [...]" [53: 26]. ${ }^{16}$ Here is an example of a situation in which there were indeed representatives of the public present at the Committee meeting, during the first reading of the bill, but only those who were specially invited. At this time, none of the conditions of open deliberation specified above were fulfilled, because these deliberations were not accessible to all the interested stakeholders, nor did they ensure sufficient diversity, and thus it cannot be said that the democratic function of the deliberative system was fulfilled. Unfortunately, such an attitude on the part of deputies, which involves selected representatives of civil society being invited and assumes that the condition of broad public consultations is thereby fulfilled, is not uncommon. That is why I consider the case study on the legislative process regarding a government bill on amending the Act on Public Benefit Activity and Voluntary Work discussed here to be extremely important: it can function as a regulatory model.

8. Eighth, the importance of mutual acknowledgements for successful cooperation during the deliberation on the bill. Iris Marion Young, criticizing the limitations associated with the overly narrow understanding of deliberation in the first phase of the development of the theory of deliberative democracy, drew attention to the importance of greetings for building mutual respect and recognition among the participants of deliberation. Young uses the term 'greetings' very broadly, from various greetings and farewells, through expressing respect and 'tickling the egos' of interlocutors, to gentle forms of flattery that are intended to facilitate the ongoing discussion. Young emphasizes that "Communicative interaction in which participants aim at reaching understanding is often peppered with gestures of politeness and deference, the absence of which is felt as coldness, indifference, insult" [45: 129]. She also points out that such greetings are particularly important in situations where the statuses of participants in the deliberation are different, and this is precisely the situation we are dealing with here in the case of a bill, in which deputies with legislative power meet with the promoters of the bill, who represent the interests of the executive, and members of the public, who have electoral authority (however distant in time, but which is to some extent taken into account by the deputies and the government). Considering in this context the mutual acknowledgements made by the participants who collaborated on the bill for the "constitution of the third sector", we can see and focus on their special significance. First we have the words of the government secretary of state J. Duda- "Once again, I thank the representatives of the public, the Council of Public Benefit Activity, and

\footnotetext{
${ }^{16}$ Because my goal is to present a certain type of attitude, rather than assessing the statements of a particular person, I exceptionally deviate from the adopted rule and the name of MP is omitted-for those interested it is available in the transcript.
} 
the Chair of the Subcommittee for this cooperation and the atmosphere during the work on the bill. Thank you very much." (1b)—who thanked both parties that took part the deliberations in the Subcommittee: the deputies, represented by the Subcommittee Chair, and the members of the public. Then we have the complimentary thanks of J.J. Wygnański, representing the public-“ "I would also like to add my thanks. I do not think I can remember a precedent for such a well consulted bill. I would like to thank the representatives of the government [...] and employees of the Department of Public Benefit in the Ministry of Labour and Social Policy" (1c)—emphasizing the awareness of representatives of NGOs of the uniqueness of the consultations and cooperation in the Polish Sejm on such a wide scale. Together, these statements build an atmosphere of mutual respect, and also recognize each party's particular contribution to the deliberations, which resulted from them taking a different position and fulfilling different roles (the promoters as the creators and defenders of the presented version of the bill, citizens as consultants who put forward proposals for new solutions, and the deputies as final decision-makers). The acknowledgments contribute to the fulfilment of the ethical function of the deliberative system.

9. Ninth, seeking a consensus. In all three statements, we can note that the deliberations on the bill involved the investment of a great deal of time and effort by all the parties concerned, and a constant striving to develop a common position on all issues where possible (I turn to the exceptions in the next section). The meetings constituted a "lively forum for the exchange of views" (1c, Wygnański), "The points of agreement reached at the meetings were presented at the Subcommittee meetings and adopted by its members" (1a, Tomaszewski), and the results achieved were "the effect of months of seeking agreement and arriving at certain decisions that were supposed to be the best possible in the circumstances" (1b, Duda), and allowed to develop an "outcome [...] which is [...] impressive" (1c). Consequently, this allows us to state that the joint deliberation of deputies, representatives of the government and the public "allows us to reach a very broad consensus" (1c). The agreement on the majority of the provisions of the bill contributes to fulfilling the ethical function of the deliberative system.

10. Tenth, constructive disagreement (applying the principle of the economy of moral disagreement). The deliberative democrats are not-as some would like to present them-naive dreamers who believe that consensus can always be reached on any matter. The attempt to put such a face $(g \varepsilon b a)$ on these democrats-as Gombrowicz would say-always amazes me, with its underlying ignorance. After all, it was none other than Rawls who, in Political Liberalism (a work which is, in my opinion-despite appearances — still underestimated in its potential and not fully recognized in political philosophy for its breakthrough proposals) attacked Kant's overly optimistic Enlightenment assumptions, according to which the deliberation of reasonable persons, if carried out in undisturbed conditions and for a sufficient amount of time, must necessarily lead to a consensus. Rawls' introduction and justification of the idea of "burdens of judgement" broke this myth and-with the elaboration of the fact of reasonable disagreement between reasonable comprehensive doctrines-brought political philosophy into the $21 \mathrm{st}$ century. Amy Gutmann and Dennis Thompson, while developing the theory of 
deliberative democracy, have also clearly perceived and emphasized this unavoidable aspect of the deliberation process, namely the possible lack of agreement between the participants. They indicate that the dynamic nature of deliberation and the accepted temporariness of the results achieved by this means (in democracy every outcome of deliberation is always open to possible discussion and change in the future) require that the principle of the economy of moral disagreement should be adhered to. This principle can also be understood more broadly, as the appropriate way to search together for solutions in a joint deliberation covering all areas of social and political co-existence (and not just moral issues). According to them: "In giving reasons for their decisions, citizens and their representatives should try to find justifications that minimize their differences with their opponents. [...] By economizing on their disagreements, citizens and their representatives can continue to work together to find common ground, if not on the policies that produced the disagreement, then on related policies about which they stand a greater chance of finding agreement" [16: 7]. The subject of this case study, namely the process of deliberation on the "constitution of the third sector' can, in my opinion, be seen as the fulfilment of the above principles. In all three of the cited statements, we can find sections in which the authors point out that they have failed to reach agreement on some issues, however this did not prevent them from developing a common position on the majority of issues that were causes of dispute. Wygnański pointed out "the issues that have yet to be resolved and which were subject to some controversy" (1c). Tomaszewski also drew attention to such contentious issues pointing out that "The Subcommittee has completed its work and submits the report" (1a), although "A decision has not been made, as it is acknowledged that this is an important problem, as to the issue..." (1a). Additionally, Duda, the representative of the government party, noted that despite all the efforts, "in some cases we were not able to reach unanimous agreement" (1b), although even on these matters the discussions were not fruitless, because as he continued "here too, we have developed positions to be implemented in a certain time frame" (1b). Good deliberation standards, which require that apart from striving to develop a common position and taking care to minimize disagreement in areas of conflict, also foster a certain ethical attitude among the participants. This attitude-which Gutmann and Thompson place a great deal of emphasis on-is the mutual respect between participants [16: 7], which constitutes the core of deliberative democracy, and can continue during the subsequent stages of the legislative process. This clearly occurred the present case study, because during the Sejm Committee meeting at which the Subcommittee's report was submitted, the representatives of all three parties continued to seek solutions to the contentious issues which all could accept and implement in the bill, in the next stage of work, i.e. during the second reading of the bill at the session of the Sejm Committee. ${ }^{17}$ The manner in which the deliberation process

\footnotetext{
17 For illustration purposes, I cite from a short exchange of views: J. J. Wygnański: “[...] maybe we could try to provide you with articles [i.e. proposals of the new draft articles to be included in the bill; comment by the author of the paper] that would regulate these matters. Maybe in the second reading they could be presented"; the Chair MP Sławomir Piechota: "If there is such agreement and the consent of a
} 
involves striving to apply the principle of minimizing disagreement contributes to building mutual respect between the participants thus contributes to fulfilling the ethical function of the deliberative system.

11. Eleventh, a lack of political bias. Wygnański, the representative of the public, drew attention to this feature of the deliberation on the Bill on Public Benefit Activity and Voluntary Work-and this is particularly important, because it sounds credible - saying: "It was very encouraging that at no stage in the work of the subcommittee was there any hint of political divisions. This was previously unheard of. We all worked in concert, which is promising for further work on the bill' (Wygnański, 1c). The deliberation took the form of the common effort to work out the best form of the bill. Here, only public justifications count, meaning those that can be accepted by all of the participants, if they are reasonable (and therefore focused on cooperation) (see [16: 3]). In his Theory of Justice, John Rawls drew attention to the fundamental importance of the public justification process when he wrote: "[...] justification is argument addressed to those who disagree with us, or to ourselves when we are of two minds. It presumes a clash of views between persons or within one person, and seeks to convince others, or ourselves, of the reasonableness of the principles upon which our claims and judgments are founded. [...] Justifying grounds do not lie ready to hand: they need to be discovered and suitably expressed, [...]. [38: 508-509]. The requirement of providing public justifications is considered to be the basis for deliberation in a deliberative democracy, whereas appealing to a particular political interest would be a violation of this. Unfortunately, in parliamentary debate, instead of argumentative power, using procedural rationale in the guise of argumentative power ('this is how the majority voted') is a very common practice. It is intended to push through the will of the political majority, without taking the reasons of the parliamentary opposition or members of the public into account. Let us note the second part of Wygnański's statement, namely the phrase "This was previously unheard of" (1c)_unambiguously suggesting the situation that representatives from the public often face in parliamentary committee and subcommittee debates. Which is why this example of deliberation is all the more remarkable, as it was characterized by a lack of political bias, thereby contributing to the undisturbed joint production of public knowledge, thus fulfilling the epistemic function of the deliberative system.

Footnote 17 (continued)

representative of the government and the chairman of the Council from the public, we may of course at the next stage of the legislative process also consider proposals for changes. There must be consent from all parties."; see [52: 8]. 


\section{Conclusions}

\subsection{Legislative Committees as Mixed Deliberative Spheres}

The role of legislative committees/subcommittees as venues of deliberation involving citizens and representatives of legislative and executive powers has been noticed by deliberative democrats. Developing his idea of distributed/delegated deliberation, Robert E. Goodin stresses not only that it is desirable to divide up the deliberative task and delegate it to sub-units, but also that they perform different tasks, and standards of deliberation and the behaviour of deliberators can differ in both types of venues, being less rigid in committees than in the full chamber. He pointed out, that "The committee is engaged in drafting (and redrafting) proposals; in giving detailed consideration to proposals line-by-line; in fact finding and in framing appropriate responses to the facts found. This is creative, cooperative work" [15: 188].

The idea of parliamentary committees as an example of mixed discursive spheres was also analysed by Caroline Hendriks. In 2006 she developed the idea of the integrated deliberative system which encompasses three types of discursive spheres: micro discursive spheres, mixed discursive spheres and macro discursive spheres. The second ones are of special interest in the context of my analysis. Mixed discursive spheres "serve to connect the micro and macro deliberative worlds. They encourage actors who might normally inhabit macro spaces (e.g. activists, interest groups, corporations) and micro venues (e.g. parliamentarians, experts, academics, government officials) to come into contact with actors who are typically underrepresented in both (e.g. individual citizens). More fundamentally, 'mixed' venues encourage the crossfertilisation of ideas across different kinds of actors, connecting broader public discourse to the conversations and decisions of the political elite" [20: 501]. In 2015 Hendriks developed the idea of mixed discursive spheres further by connecting it with the idea of the 'designed coupling' of citizens and political elites in the deliberative system. She especially stressed the role of legislative committees as possible venues for such a coupling of MPs with representatives of the public, but she also noticed that making this combination workable demands both appropriate institutional design and the proper attitude of all the participants in the deliberation. This is due to the fact that: "To be effective 'designed coupling' requires actors to step outside their comfort zone to build new relationships and engage in new spaces with different sets of ideas, actors and rules. This can be facilitated by institutional design, but it also requires leaders and champions who are well placed to encourage actors to think differently" [21: 57].

These two issues will be analysed in the next sections as the problem of internal and external deliberation and the deliberative stance or deliberative mindset. 


\subsection{Internal/External Deliberation ${ }^{18}$}

Both Goodin and Hendriks stressed the differences in procedures, the behaviour of participants and the performed tasks between the deliberation in the full chamber (and committee) and subcommittee deliberation. Deliberation open to the public, usually transmitted by official parliamentary internet media, although it ensures transparency, has its own flaws, as deliberative researchers have already underlined. John Parkinson noticed that "The work of representation and collective decisionmaking requires not just moments of publicity and accessibility, but moments of privacy too" [35: 442]. Similarly, Joseph M. Bessette pointed out that "in some circumstances deliberation may benefit from restrictions on public scrutiny" [4: 159]. This issue was analysed in detail by John Ferejohn and Pasquale Pasquino, who distinguished two types of institutional deliberation: external, which is available directly or through the media for all interested members of the public; and internal, which takes place in the seclusion of offices (parliamentary, court, etc.) ${ }^{19}$

In modern democracies with mass media, the former often "aims to convince those who are not in the room" [14: 209]. During external deliberation, representatives of opposing parties are less prone to compromise and exchanging arguments, let alone changing their position through being convinced by arguments delivered by the opposition.

Participants in the second kind of deliberation aim to engage in a common search for the best solutions and are open to exchanging reasons. Ferejohn describes the advantages of internal deliberation, underlining that "it permits participants to speak to each other without an external and poorly informed audience to impress. Members of internally deliberative bodies are free to change their minds or views without worrying about their public reputations for inconsistency. Moreover, internal deliberation works to shield members from pressures of bribery or intimidation from external groups. [...] In any case, internally deliberative processes may provide an environment in which issues can be decided free from coercion and temptation and in that way approach what Habermas has called an ideal speech situation. At least from the viewpoint of those in the room" [14: 209].

In Deliberative Politics in Action. Analyzing Parliamentary Discourse Steiner et al. go a step further and put forward the hypothesis that: "Non-public arenas are characterized by a higher quality of parliamentary deliberation than public arenas" [39: 88]. In their opinion, a model example of such deliberations are parliamentary committees or subcommittees (in the Polish Sejm, especially the latter would be exemplary), which "are small face-to-face groups that operate over an extended period of time, which may create habits of working together and friendships, as well as knowledge about each other. These outcomes, in turn, may foster trust and, as such, lubricate the deliberative process" [39: 88]. The lack of direct pressure, which is always present when there is a need to play the role of political

\footnotetext{
18 This issue is also associated with a third, important problem, namely the issue of deliberation in enclaves, but this is beyond the scope of this article. See: $[6,24]$.

19 These terms were introduced by John Ferejohn and Pasquale Pasquino in [13: 1671-1704].
} 
competitors, allows MPs to work together and focus on finding the best legislative solution, instead of using confrontational language and putting on the rhetorical performances typical for debates watched by potential voters. Steiner et al. point out that: "Non-public legislative bodies such as parliamentary committees allow legislators to deliberate without external interference, lower the pressures to follow the wishes of constituents, and make it easier for politicians to reflect, to show respect for the claims of others, or even to change their opinions" [39: 88].

The analysis of the speeches of key participants in the legislative process on the bill on the Act on Public Benefit Activity and Voluntary Work shows that in fact the actual deliberation of the permanent Subcommittee concerning cooperation with non-governmental organizations took the form of internal deliberation, as characterized above, with all its advantages.

\subsection{Stakeholders/Ordinary Citizens}

Another issue I would like to draw attention to in these final conclusions concerns the type of subjects representing the public in the deliberative legislative process concerning the aforementioned bill on the Act on Public Benefit Activity and Voluntary Work. It should be noted that in both the public hearings and the work in the Sejm Subcommittee it was the representatives of NGOs and local self-government units that participated, but not ordinary citizens. This is a feature of the legislative deliberation process under analysis, because-as Kahane et al. emphasize - research on deliberative democracy often does not highlight the difference between these two types of subjects representing society. They underlie the analytical value in the distinction between stakeholders (representatives of organized groups) and citizens (unaffiliated/lay/ordinary individuals), because "there are important differences between participating as representatives of organized groups or as individual citizens, and also differences in how these roles tend to play out in deliberative processes [...]" [23: 5]. Kahane et al. enumerate several reasons to involve stakeholders in deliberative processes, pointing out that stakeholder groups: 1. can provide an efficient route to engaging social and political diversity relevant to an issue; 2. provide a publicly legible route to engaging social and political diversity relevant to an issue; 3. may represent particular perspectives and interests more effectively than lay citizens; 4. may exert influence on decision-makers, administrators, and the broader political sphere; 5. may shift in their position, which can resonate through an organization and constituency [23: 9-11]. The analysed case study seems to confirm, both on the normative and practical levels, the abovementioned effects of the participation of public stakeholders in the deliberative legislative process of 'the constitution of the third sector'.

The interest of representatives of the NGOs (stakeholders) in the legislative process of 'the constitution of the third sector' is obvious, and the public knowledge they developed on the basis of everyday practice was one of their main assets. But the readiness of the legislators and representatives of the government 
to accept the broad involvement of stakeholders shows their open-minded attitude to the legislative process.

\subsection{Deliberative Stance/Deliberative Mindset}

In deliberative democratic theory, there recently emerged two interesting proposals for an analytic understanding of the attitude of deliberating parties which is necessary for successful cooperation.

David Owen and Graham Smith have latterly referred to the disposition of participants in deliberation: they should be open-minded, unprejudiced and non-discriminatory. They name this disposition the deliberative stance, defined as "a relation to others as equals engaged in mutual exchange of reasons oriented as if to reaching a shared practical judgement" [31: 228]. There are many possible stances which can be adopted by participants, depending on the institutional settings or the human factors, but the main ones are contestatory/agonistic, or deliberative [31:232].

Similarly, in The Spirit of Compromise Amy Gutmann and Dennis Thompson developed the concept of a mindset, which "is a cluster of attitudes and arguments that incline individual to organize thinking and action in a way that makes some consideration sand choices more salient than others. It is a composite of cognitive and dispositional states - influencing both how one tends to conceptualize and argue about phenomena and how one is incline to act on the conceptualizations and arguments". ${ }^{20}$ They distinguish between compromising and uncompromising mindsets, and point out that both institutional design that is conducive to deliberation-or not, and personal relations based on trust or adversarial relations with other participants in deliberation, can influence shifts from one mindset to another [17: 65]. Of particular interest in terms of this case study analysis is that Gutmann and Thompson place special emphasis on the following possibility: "Being held responsible for passing legislation can activate the compromising mindset" [17: 65].

Adopting a deliberative stance or compromising mindset facilitates deliberation and enhances social learning, because in such a situation "stakeholders are capable of learning from each other by building up new relationships through participatory communication, establishing trustworthiness with each other and then opening up to appreciate previously opposed views and get them converged through compromises" [25: 43]. The analysis of the presented speeches shows that all the parties involved adopted a deliberative mindset in the internal deliberation during the subcommittee meetings. All the parties cooperated for the achievement of the best workable law.

So finally, it is necessary ask: What were the conditions that made this possible in the case of the bill on the Act on Public Benefit Activity and Voluntary Work? The answer is connected with identification of two factors: institutional and human. To be workable, our research from the perspective of the systemic

\footnotetext{
${ }^{20}$ [17: 64-65]. The authors mention the process of framing, which is analyzed in political science as "the close conceptual cousin to mindsets" [17: 66]. Analyzing the presented case study from the perspective of framing would be an interesting endeavor, but far beyond the scope of this article. For further discussion, see: Mauro Barisione [1: 1].
} 
approach to deliberative democracy has to be based on the assumption that both factors, human and institutional, are equally important in research on and evaluation of institutional performance. Indisputably, the influence of institutional design on upholding or undermining democratic deliberation in power holding venues cannot be overestimated. However, in my opinion, one of the greatest dangers for the systemic approach is connected with analysing institutions from the perspective of institutional autonomy in a way that reduces the role, intentions and competences of participating individuals - whether they be ordinary citizens, stakeholders or politicians. Concentrating exclusively-or even just mainly-on institutions, while developing the systemic approach to deliberative democracy, lets the genie of functionalism out of the bottle, with all its fully justified critique.

On the institutional level, the design of Polish law concerning public consultations of the draft bill at the pre-parliamentary stage and the bill at the parliamentary stage of the process of law-making, enables consultation with the wider citizenry and stakeholders. But if the institutional design is conducive to all the interested parties engaging in deliberation, in that case why is it rare, and why are the citizens and stakeholders usually disappointed with the consultation process?

The answer concerns human factors: the attitudes of the promotors of the bill and representatives of the legislative bodies to broad public consultation, and their capacity to adopt a deliberative stance. The institutional settings conducive to developing the deliberative stance of all the interested parties should not only create opportunities for common deliberation, but also create them in the right time in the legislative process. The interests and concerns of diverse stakeholders should be taken into consideration at an early stage of the law-making process. It would enable the authors of a draft bill to promote the explicit presentation and justification of proposed policy changes, and at the same time allow the interested parties to be given an opportunity to express their opinions. The presentation of a variety of ideas and perspectives can enrich the law-making process at the early stages of drafting a bill, whereas at more advanced stages of the law-making process such contributions can be treated by the promoters of a bill as more of a hindrance than a help. Early presentation allows all the interested parties to make an assessment of the importance of the represented stakes. Although working with stakeholders is generally considered common practice in the law-making processes, and despite the fact that public consultations of a bill are often demanded by law, it is often the case that only certain stakeholders actually have a say in the legislative process. Therefore, it is crucial to involve all the different types of stakeholders throughout the legislative process, addressing their specific knowledge. This helps to legitimise the bill and enhance its quality. Stakeholder involvement supports the development of a more effective and legitimate process of law-making.

It was previously mentioned that, due to its fundamental importance for the functioning of the 'third sector' in the public sphere in Poland, Wygnański described the Act on Public Benefit Activity and Voluntary Work as "the constitution of the mutual relations between the public administration and the third sector" [51: 5]. In my opinion, the analysed case study of the legislative process concerning the government bill amending the Act on Public Benefit Activity and Voluntary Work in the Polish Sejm, based on the transcript of speeches of its main participants, shows that 
the cooperation of MPs, members of the public and representatives of the government (promoters of the bill) during the work of the Permanent Subcommittee on the issue of cooperation with non-governmental organizations allows for the conclusion, that it was - to borrow Goodin's phrase-'good enough deliberation' [15: 194] to be described as a model of good practices when it comes to deliberative cooperation in parliament between representatives of the political authorities and the public. The presented analysis shows that it is possible to evaluate the Polish Sejm as an institution which can create internal sites, which integrate the need for inclusive deliberation open to the public stakeholders (and citizens) with decision-making power. The question of why it is so rare in parliamentary practice and how this can be changed is open to further research, as obviously "...the deliberative systems approach remains a work in progress..." [21: 43].

Acknowledgements This article was prepared within the framework of the grant of the National Science Centre No. DEC-2015/19/B/HS5/03114.

Open Access This article is distributed under the terms of the Creative Commons Attribution 4.0 International License (http://creativecommons.org/licenses/by/4.0/), which permits unrestricted use, distribution, and reproduction in any medium, provided you give appropriate credit to the original author(s) and the source, provide a link to the Creative Commons license, and indicate if changes were made.

\section{References}

1. Barisione, Mauro. 2012. Framing a Deliberation. Deliberative Democracy and the Challenge of Framing Processes. Journal of Public Deliberation 8(1), Article 2.

2. Bächtiger, André. 2016. Debate and Deliberation in Parliament. In The Oxford Handbook of Legislative Studies, ed. Kaare Strøm, Thomas Saalfeld, and Shane Martin, 145-166. Oxford: Oxford University Press.

3. Bendix, William. 2016. Bypassing Congressional Committees: Parties, Panel Rosters, and Deliberative Processes. Legislative Studies Quarterly 41(3): 687-714.

4. Bessette, Joseph M. 1994. The Mild Voice of Reason: Deliberative Democracy and American National Government. Chicago: University of Chicago Press.

5. Cern, Karolina M. 2014. The Counterfactual Yardstick. Normativity, Self-Constitutionalization and the Public Sphere. Frankfurt am Main: Peter Lang Edition.

6. Chambers, Simone. 2012. Behind Closed Doors: Publicity, Secrecy, and the Quality of Deliberation. The Journal of Political Philosophy 12(4): 389-410.

7. Chambers, Simone. 2012. Deliberation and Mass Democracy. In Deliberative Systems. Deliberative Democracy at the Large Scale, ed. John Parkinson and Jane Mansbridge, 52-71. Cambridge: Cambridge University Press.

8. Cohen, Joshua. 1989. Deliberation and Democratic Legitimacy. In The Good Polity. Normative Analysis of the State, ed. Alan Hamlin and Philip Pettit, 17-34. Oxford: Basil Blackwell.

9. Dryzek, John S. 2009. Democratization as Deliberative Capacity Building. Comparative Political Studies 42(11): 1379-1402.

10. Dryzek, John S., and Simon Niemeyer. 2010. Foundations and Frontiers of Deliberative Governance. Oxford: Oxford University Press.

11. Elster, Jon. 1986. The Market and the Forum. In Foundations of Social Choice Theory, ed. Jon Elster and Aanund Hylland, 103-132. Cambridge: Cambridge University Press.

12. Elstub, Stephen, Selen Ercan, and Ricardo Fabrino Mendonça. 2016. The Fourth Generation of Deliberative Democracy. Critical Policy Studies 10(2): 139-151.

13. Ferejohn, John, and Pasquale Pasquino. 2004. A Constitutional Adjudication: Lessons from Europe. University of Texas Law Review 82: 1671-1704. 
14. Ferejohn, John. 2008. Conclusion: The Citizens' Assembly Model. In Designing Deliberative Democracy: The British Columbia Citizen's Assembly, ed. Mark E. Warren and Hilary Pearse, 192213. Cambridge: Cambridge University Press.

15. Goodin, Robert E. 2005. Sequencing Deliberative Moments. Acta Politica 40: 182-196.

16. Gutmann, Amy, and Dennis Thompson. 1996. Why Deliberative Democracy? Cambridge, MA: The Belknap Press of Harvard University Press.

17. Gutmann, Amy, and Dennis Thompson. 2012. The Spirit of Compromise. Why Governing Demands It and Campaigning Undermines It. Princeton: Princeton University Press.

18. Habermas, Jürgen. 1992. Faktizität und Geltung. Beiträge zur Diskurstheorie des Rechts und des demokratischen Rechtsstaats. Frankfurt am Main: Suhrkamp Verlag.

19. Habermas, Jürgen. 1996. Between Facts and Norms. Contribution to a Discourse Theory of Law and Democracy (trans: Rehg, William). Cambridge MA: The MIT Press.

20. Hendriks, Carolyn M. 2006. Integrated Deliberation: Reconciling Civil Society's Dual Role in Deliberative Democracy. Political Studies 54: 486-508.

21. Hendriks, Carolyn M. 2016. Coupling Citizens and Elites in Deliberative Systems: The Role of Institutional Design. European Journal of Political Research 55: 43-60.

22. Juchacz, Piotr W. 2015. Deliberative Public Philosophy. An Analysis of the Institution of a Public Hearing in the Sejm of the Republic of Poland from the Point of View of a Systemic Approach to Deliberative Democracy. Poznan: Adam Mickiewicz University Press. [in Polish]

23. Kahane, David, Loptson, Kristjana, Herriman, Jade, and Hardy, Max. 2013. Stakeholder and Citizen Roles in Public Deliberation. Journal of Public Deliberation 9(2), Article 2.

24. Karpowitz, Christopher F., Chad Raphael, and Allen S. Hammond. 2009. Deliberative Democracy and Inequality: Two Cheers for Enclave Deliberation Among the Disempowered. Politics \& Society 37(4): 576-615.

25. Liu, Xinyue. 2011. Can Participatory Governance Influence Urban Water Pricing Reform? A Public Hearing Case Study of City Chengdu, China. Saarbruecken: Lambert Academic Publishing.

26. Manin, Bernard. 1987. On Legitimacy and Political Deliberation. Political Theory 15(3): 338-368.

27. Mansbridge, Jane J. 1990.The Rise and Fall of Self-Interest in the Explanation of Political Life life. In Beyond Self-Interest, ed. Jane J. Mansbridge, 3-22. Chicago: University of Chicago Press.

28. Mansbridge, Jane J. 1999. Everyday Talk in the Deliberative System. In Deliberative Politics. Essays on "Democracy and Disagreement", ed. Stephen Macedo, 211-239. New York: Oxford University Press.

29. Mansbridge, Jane, Bohman, James, Chambers, Simone, Christiano, Thomas, Fung, Archon, Parkinson, John, Thompson, Dennis F. and Warren, Mark E. 2012. A systemic Approach to Deliberative Democracy. In Deliberative Systems. Deliberative Democracy at the Large Scale. ed. John Parkinson, and Jane Mansbridge, 1-26. Cambridge: Cambridge University Press.

30. Norris, Pippa (ed.). 1999. Critical Citizens. Global Support for Democratic Government. Oxford: Oxford University Press.

31. Owen, David, and Graham Smith. 2015. Survey Article: Deliberation, Democracy, and the Systemic Turn. Journal of Political Philosophy 23(2): 213-234.

32. Parkinson, John. 2006. Deliberating in the Real. World Problems of Legitimacy in Deliberative Democracy. Oxford: Oxford University Press.

33. Parkinson, John, and Jane Mansbridge (eds.). 2012. Deliberative Systems. Deliberative Democracy at the Large Scale. Cambridge: Cambridge University Press.

34. Parkinson, John. 2013. How Legislatures Work-And Should Work-As Public Space. Democratization 20(3): 438-455.

35. Parkinson, John. 2018. Deliberative Systems. In The Oxford Handbook of Deliberative Democracy, ed. André Bächtiger, John S. Dryzek, Jane Mansbridge, and Mark E. Warren, 432-446. Oxford: Oxford University Press.

36. Quirk, Paul J., William Bendix, and André Bächtiger. 2018. Institutional Deliberation. In The Oxford Handbook of Deliberative Democracy, ed. André Bächtiger, John S. Dryzek, Jane Mansbridge, and Mark E. Warren, 273-299. Oxford: Oxford University Press.

37. Rawls, John. 1993. Political Liberalism. New York: Columbia University Press.

38. Rawls, John. 1999. Theory of Justice. Revised Edition. Cambridge, MA: The Belknap Press of Harvard University Press. 
39. Steiner, Jürg, André Bächtiger, Marcus Spörndli, and Marco R. Steenbergen. 2004. Deliberative Politics in Action Analyzing Parliamentary Discourse. Cambridge: Cambridge University Press.

40. Sunstein, Cass R. 1984. Naked Preferences and the Constitution. Columbia Law Review 84(7): 1689-1732.

41. Sunstein, Cass R. 1985. Interest Groups in American Public Law. Stanford Law Review 38: $29-87$.

42. Thompson, Dennis. 2008. Deliberative Democratic Theory and Empirical Political Science. Annual Review of Political Science 11: 497-520.

43. Uhr, John. 1999. Deliberative Democracy in Australia: The Changing Place of Parliament. Cambridge: Cambridge University Press.

44. Uhr, John. 2003. Parliament and Public Deliberation: Evaluating the Performance of Parliament. The University of New South Wales Law Journal 24(3): 708-723.

45. Young, Iris Marion. 1996. Communication and the Other: Beyond Deliberative Democracy. In Democracy and Difference. Contesting the Boundaries of the Political, ed. Seyla Benhabib, 120135. Princeton: Princeton University Press.

\section{Transcripts of the Parliamentary Committees Meetings}

46. From the Meeting of the Social Policy Committee (no. 123), Bulletin 2147/V term, 27 June 2007, the Chancellery of the Sejm-Office of Parliamentary Committees, Warsaw 2007. http://orka.sejm.gov. p1/Biuletyn.nsf/0/2544941C24ED6F64C12573100031C30F/\$file/0214705.pdf.

47. From the Meeting of the Social Policy Committee (no. 140), Bulletin 2315/V term, 9 September 2007, the Chancellery of the Sejm-Office of Parliamentary Committees, Warsaw 2007. http://orka. sejm.gov.pl/Biuletyn.nsf/0/B76489827A41FC2BC1257377003818C2/\$file/0231505.pdf.

48. From the Meeting of the Social Policy and Family Committee (no. 137), Bulletin 2042/VI term, 19 March 2009, the Chancellery of the Sejm-Office of Parliamentary Committees, Warsaw 2009. http://orka.sejm.gov.pl/Biuletyn.nsf/0/3A8845F495382500C125758D003918A6/\$file/0204206.pdf.

49. From the Meeting of the Social Policy and Family Committee (no. 145), Bulletin 2125/VI term, 21 April 2009, the Chancellery of the Sejm-Office of Parliamentary Committees, Warsaw 2009. http://orka.sejm.gov.pl/Biuletyn.nsf/0/BA3C99494059AE67C12575AE004661D6/\$file/02125 06.pdf.

50. From the Meeting of the Social Policy and Family Committee (no. 148), Bulletin 2173/VI term, 23 April 2009, the Chancellery of the Sejm-Office of Parliamentary Committees, Warsaw 2009. http://orka.sejm.gov.pl/Biuletyn.nsf/0/6F840C4D2146FB0CC12575AD0030F852/\$file/02173 06.pdf.

51. From the Meeting of the Social Policy and Family Committee (no. 189), Bulletin 2791/VI term, 7 October 2009, the Chancellery of the Sejm-Office of Parliamentary Committees, Warsaw 2009. http://orka.sejm.gov.pl/Biuletyn.nsf/0/75893068AA948D55C125765C004E2C7A/\$file/02791 06.pdf.

52. From the Meeting of the Social Policy and Family Committee (no. 191), Bulletin 2820/VI term, 08 October 2009, the Chancellery of the Sejm-Office of Parliamentary Committees, Warsaw 2009. http://orka.sejm.gov.pl/Biuletyn.nsf/0/2798D5C0D1C4C72DC125765B002B755E/\$file/02820 06.pdf.

53. From the Meeting of Culture and Media Committee (no. 122), Bulletin 3852/VI term, 22 June 2010, the Chancellery of the Sejm-Office of Parliamentary Committees, Warsaw 2009. http://orka.sejm. gov.pl/Biuletyn.nsf/0/DFD40F6262362473C125775F00361F16/\$file/0385206.pdf.

54. "1727-Explanatory Memorandum", to the government's bill amending the Act on public benefit activity and volunteering and some other acts (Print 1727), 16-02-2009. http://orka.sejm.gov.pl/ Druki6ka.nsf/wgdruku/1727,

55. "1810-Explanatory Memorandum", to the government's bill amending the Act on public benefit activity and volunteering and some other acts (Print 1810), 01-06-2007. http://orka.sejm.gov.pl/ Druki5ka.nsf/wgdruku/1810.

Publisher's Note Springer Nature remains neutral with regard to jurisdictional claims in published maps and institutional affiliations. 